\title{
WESTERNIZATION AND COLONIZATION OF THE MIND IN CHINUA ACHEBE'S “DEAD MEN'S PATH”
}

\author{
Maria Regina Anna Hadi Kusumawardani*
}

English Language Studies, Postgraduate Program, Universitas Sanata Dharma, Daerah Istimewa Yogyakarta 55281, Indonesia

\section{ARTICLE INFO}

Keywords:

Dead Men's Path

British colonialism

Westernization

Colonization of the mind

Article History:

Received: 07/10/2021

Accepted: 18/11/2021

Available Online:

$30 / 11 / 2021$

\begin{abstract}
A B S T R A C T
British occupation in Nigeria has brought several impacts to the native land and also the indigenous people. Westernization and colonization of the mind are two inseparable effects of colonialism. These two issues are oftentimes depicted in literary works focusing on colonialism as their theme. The aim of this study is to analyze the issues of westernization and colonization of the mind raised in Chinua Achebe's "Dead Men's Path." The data were taken from quotes that prove the existence of these issues from a short story entitled "Dead Men's Path" by Chinua Achebe and analyzed them using Homi Bhabha's theory of mimicry and Ngũg̃ wa Thiong'o's theory of colonization of the mind. The results showed that westernization and colonization of the mind have affected Michael Obi, the main character in the story. Westernization influences Obi to adopt modern life and Western thoughts that show the process of mimicry, while colonization of the mind makes Obi downgrades Nigerian cultures. The issue of the management of land was also found in the story as a continuation of the previous problems. "Dead Men's Path" by Chinua Achebe reveals that British colonialism has changed the perspectives of Nigerian elites, as seen in Michael Obi's story.
\end{abstract}

2442-305X / (C) 2021 The Author, this is open access article under the (CC-BY-NC) license (https://creativecommons.org/licenses/by-nc/4.0/), DOI:10.19105/ojbs.v15i2.5168

\footnotetext{
$\overline{\text { * Corresponding Author: }}$

Email address: mariaregina8839@gmail.com (M. R. A. H. Kusumawardani)
}

\section{A. Introduction}

Western colonialism is part of history that directly and indirectly shapes the world years afterward. It happened because colonized territories were seen by the colonizers as a main provider of essential natural resources. ${ }^{1}$ In order to

1 Lea Ypi, "What's Wrong with Colonialism," Philosophy \& Public Affairs 41, no. 2 (2013): 158$191 \mathrm{https} / / /$ doi.org/10.1111/papa.12014. obtain what they were looking for, the colonizers often came and occupied regions that were miles away from their hometown. Even under colonialism, the colonizers worked on an enormous scale of exploiting one country, ${ }^{2}$ taking all they needed and wanted from the colonized.

\footnotetext{
2 Irfan Habib, "Towards a Political Economy of Colonialism," Social Scientist 45, no. 3/4 (2017): 915, https://www.jstor.org/stable/26380342.
} 
As a result, Western colonialism has left numerous impacts on the colonized countries, either good or bad. It has affected most of the aspects existing in the colonized before the colonizers came and occupied the land. Infrastructures and technologies are two examples of the concrete impacts from Western colonialism that we can see even until today.

In Africa, for example, the effects of colonialism are more complex than the buildings and technologies left by the colonizers. Western education and civilization brought by the colonizers were completely different from African culture because colonial education was not rooted in African culture and therefore could not support any meaningful development within the African environment because it was not coherent with African culture. ${ }^{3}$ The Western knowledge that Africans learned through colonial education then gradually brought native Africans to abandon their own indigenous technological skills and education. Besides, related to African art and tradition of worship, the culture of African people in the contemporary era has been immensely superseded by Western culture influence, where African music and dances accompanying African worshippers are replaced by band-set and English songs. ${ }^{4}$

\footnotetext{
${ }^{3}$ Stephen Ocheni and Basil C. Nwankwo, "Analysis of Colonialism and Its Impact in Africa," CrossCultural Communication 8, no. 3 (2012): 46-54, https://doi.org/10.3968/j.ccc.1923670020120803.11 89.

4 Clifford Meesua Sibani, "Impact of Western Culture on Traditional African Society: Problems
}

In order to understand colonialism and its impacts towards both the colonizer and the colonized, many critics and scholars frequently use postcolonial study or postcolonialism. According to Overbey, the term postcolonial, which functions as a critical term, implies "the social conditions and subjectivities that exist within/during colonial rule and occupation, after independence, and also in diasporic and transnational communities." ${ }^{5}$ This definition is also supported by Young, arguing that postcolonialism aims to "reconstruct Western knowledge formations, reorient ethical norms, turn the power structures of the world upside down, refashion the world below." ${ }^{6}$

Besides, postcolonialism tries to portray colonialism not only from the colonized' perspective but also from the colonizer, since colonialism involves both sides, leaving impacts as well as scars for those who were trapped in this colonial web. However, it is important to understand that the prefix 'post' in either postcolonialism or postcolonial does not literally mean 'after' the colonial period. Instead, it has a broader meaning. It deals with the idea that colonialism still has several impacts in forming our world until today. ${ }^{7}$

and Prospects," International Journal of Religion and Human Relations 10, no. 1 (2018): 56-72.

${ }^{5}$ Karen Eileen Overbey, "Postcolonial," Studies in Iconography $33 \quad$ (2012): 145-56, https://www.jstor.org/stable/23924279.

6 Robert JC Young, "Postcolonial Remains," New Literary History 43, no. 1 (2012): 19-42, https://doi.org/10.1353/nlh.2012.0009.

7 Sanjay Seth, "Postcolonial Theory and the Critique of International Relations," Millennium 40, 
In relation to literature, postcolonial study is applied in literary works to study the depiction of Western colonialism and uncover the colonial enterprises and violence experienced by the indigenous people. It encourages critics and scholars to analyze writings discussing colonialism that once happened in the authors' home countries. With a huge number of writings under the theme of Western colonialism, postcolonial critics and students are challenged to see the issues of the colonial era portrayed in postcolonial literature. Moreover, the postcolonial study can also help them track down the colonizer's footprints left in the colonized's behavior, perspective, and thoughts. By analyzing postcolonial literature using theories from postcolonial studies, we can observe the mark left by the colonial era. ${ }^{8}$

Chinua Achebe is one of the writers whose works are very influential for postcolonial study in literature. Since he was born in Ogidi, an Igbo village in Nigeria, his writings are much influenced by the Nigerian cultures. Besides, his works also raise the imposition of Western customs and values upon traditional African society, ${ }^{9}$ depicting the issues and impacts of colonialism since Nigeria is one

\footnotetext{
no. 1 (2011): 167-83,
https://doi.org/10.1177/0305829811412325.

8 Liza Putri and Katherine Clayton, "The Identity Issue of the Colonized and the Colonizer in Cloud Nine by Caryl Churchill," International Journal of Cultural and Art Studies 4, no. 1 (2020): 1-8, https://doi.org/10.32734/ijcas.v4i1.3620.

9 The Editors of Encyclopaedia Brittanica, "Chinua Achebe: Nigerian Author," in Encyclopedia Britannica, accessed October 25, 2021, https://www.britannica.com/biography/ChinuaAchebe.
}

of the countries in Africa that was colonized by the British from the early 19th until around mid-20th century.

Achebe has already published several writings during his lifetime, including the themes of colonialism in Nigeria. Through his works, he expresses his concerns related to British colonialism in his hometown. Harry Garuba argues that Achebe's novels were well-written in order to show that during and after British colonialism, actually African societies "were not mindless and savage but were culturally sophisticated, functioning entities with their own rationalities and codes." ${ }^{10}$ Besides his novels, he is also popular for his short stories. They are essential for postcolonial critics and students because these stories give insights into British colonialism in Nigeria. "Dead Men's Path" is one of Achebe's short stories included in the list of literary works under the postcolonial study.

This short story is worth discussing since it is one of Achebe's short stories that raise the issues of colonialism in Africa that affected local African cultures. Along with other stories compiled in Girls at War and Other Stories, this short story was drawn from literary journals and magazines. ${ }^{11}$ It shows that although "Dead Men's Path" did not receive any specific award, it actually has gained

\footnotetext{
${ }^{10}$ Harry Garuba, "Chinua Achebe and the Struggle for Discursive Authority in the Postcolonial World," PMLA 129, no. 2 (2014): 246-48, https://www.jstor.org/stable/24769453.

11 Komenan Casimir, "Promotion of Igbo Culture in Chinua Achebe's Girls at War and Other Stories," Global Journal of Arts, Humanities and Social Sciences 6, no. 9 (2018): 26-41.
} 
global recognition from many readers who are interested in postcolonial literary texts. Besides, "Dead Men's Path" promotes Igbo-based themes that mark the characteristics of Achebe's writing.

"Dead Men's Path" tells the readers about a young headmaster who is appointed to rule an old school in a small village, but some of his decisions are against the indigenous cultures that have lived there for a long time. It represents the situation in Nigeria during British colonialism when two contradictory ideas meet and affect the colonized's perspectives towards his own cultures. In the story, Achebe describes the young headmaster as a Nigerian who sees the Westerners as superior to his own people. The social identity of a community, which is the Western colonizer, makes certain groups perceive themselves as more positive and superior than others. ${ }^{12}$ Therefore, this young headmaster also tries to adopt the Western thoughts and lifestyle in his life. It can be said that this young Nigerian headmaster has been 'westernized' because of British colonialism and occupation in Nigeria.

Under the discussion of westernization, many researchers strive to find the issues of westernization in several aspects due to colonialism. For example, in 2011, Sairin focused on the debates and issues of westernization in Indonesia

\footnotetext{
${ }^{12}$ Nensilianti, Sy. Fatma Al-Khiyyed, and Hasvivi Tri Anjarsari Fahrir, "Colonial Racial Ethnocentrism Towards Indigenous People in a Short Story Collection 'Semua Untuk Hindia' by Iksaka Banu (A Postcolonial Study)," OKARA: Jurnal Bahasa dan Sastra 15, no. 1 (2021): 1-21, https://doi.org/10.19105/ojbs.v15i1.3982.
}

before and after independence, during the new order, and post-Soeharto era. ${ }^{13}$ Prianti's research in 2018 examined how modernization and westernization as contemporary conditions in postcolonial Indonesia serve as the background to the narratives provided by men's lifestyle magazines. ${ }^{14}$ Souad and Ramdane's study conducted in 2019 argued that teaching English either as a second language or a medium of instruction can be considered as a tool to spread Western cultural dominance under the pretext of globalization. ${ }^{15}$ Nwinya's research in 2019 criticized modernization and westernization in Africa, arguing that the colonial factor was important to westernization in Africa itself. A concrete example of this process is seen in the actions done by Western Christian missionaries and African returnees from Diaspora. Nwinya suggests that Africa will develop and maintain its civilization simultaneously when it becomes more conscious of what it gives and takes in the process of modernization. ${ }^{16}$

\footnotetext{
${ }^{13}$ Sjafri Sairin, "Modernization and Westernization: A Never-Ending Discourse in Indonesia," Journal of Governance and Development 7 (2011): 1-7.

14 Desi Dwi Prianti, "Towards the Westernized Body: A Popular Narrative Reinforced by Men's Lifestyle Magazines in Indonesia," Inter-Asia Cultural Studies 19, no. 1 (2018): 103-16, https://doi.org/10.1080/14649373.2018.1422351.

${ }^{15}$ Merah Souad and Tahraoui Ramdane, "Learning English in the 21st Century: For Globalization or Westernization?," International Journal of Humanities and Social Science 9, no. 6 (2019): 165-72, https://doi.org/10.30845/ijhss.v9n6p20.

16 Stephen Chijioke Nwinya, "The Conflate of Modernization and Westernization and Africa's Quest for Authentic Civilization and Development," IOSR Journal of Humanities and Social Science 24, no. 10 (2019): 59-65
} 
In this research, "Dead Men's Path" is analyzed under the umbrella of postcolonial study. This research was conducted to see how Achebe presents a collision and confrontation between imperialist ideas (which later supports colonization) and Nigerian beliefs and how it impacts the society living near the young headmaster's school. Besides, this research also focuses on how British colonialism controls the native land using the natives' own hands.

Compared to the previous studies reviewed, this study focuses on analyzing the forms of westernization depicted in a literary work entitled "Dead Men's Path" written by Chinua Achebe, an African writer who was active in criticizing colonialism in Africa through his works. Besides, this study also pays attention to the colonization of the mind, which is still closely related to westernization. Both issues of westernization and colonization of the mind are studied using postcolonial theories in order to see how these problems are experienced by the characters in the short story.

The aim of this research is to analyze the issues of westernization and colonization of the mind raised in Chinua Achebe's "Dead Men's Path" by discussing the conflict between the Nigerian intellectuals (as seen in the story where Michael Obi and the teachers are likely to support the Western ideologies) and the villagers related to a sacred path preserved by the natives.

\section{B. Method}

This research was conducted using a qualitative approach. The analysis and the results are in the form of description. This research data were quotations taken from the short story, which contain the issues and impacts of colonialism and westernization during British occupation in Nigeria. The data were taken from Chinua Achebe's "Dead Men's Path", written in 1953. This short story was chosen from Girls at War and Other Stories, which is a compilation of Achebe's short stories published by Anchor Books in 1973.

"Dead Men's Path" focuses on a character who is the young headmaster. Although this short story chooses the British colonial era as the main situation where several events happen, no British character speaks or is highlighted in this story.

To analyze the data, this research applied theories and concepts from two scholars. The first one is Homi Bhabha, with his theory of mimicry. This theory talks about mimicry as one of the most elusive and efficient colonial power and knowledge strategies. ${ }^{17}$ The colonizers use colonial mimicry to infuse their ideas in the colonized people in order to make them subjects of difference who are "almost the same, but not quite." 18 It gradually affects the colonized's behavior and directs them to feel the desire to be similar to and feel accepted by the colonizers.

17 Homi K. Bhabha, The Location of Culture (London: Routledge, 1994), 85.

${ }^{18}$ Bhabha, 86. 
However, Bhabha argues that mimicry can be "at once resemblance and menace" for the colonizers themselves, because now the colonized people understand, although partially, how the colonizers think and behave. ${ }^{19}$ The menace now reverses the position of the colonizer and the colonized, in which "the observer becomes the observed and 'partial' representation rearticulates the whole notion of identity and alienates it from essence." ${ }^{20}$ In this study, the theory of mimicry is used to analyze westernization in which the colonized adopts and mimics Western cultures, as seen in "Dead Men's Path."

The second theory is from Ngũgĩ wa Thiong'o, which is about the colonization of the mind. Colonialism enforces its control of the social production of wealth through military submission, followed by a political dictatorship, but all these forms of control will not be successful if the colonized's mind is left untouched by colonialism. Therefore, colonialism needs to dominate the mental universe of the colonized by using culture to control the way people see themselves and their relationship to the world. ${ }^{21}$

Thiong'o argues that decolonization of the mind encompasses two aspects. The first one is "the destruction or the deliberate undervaluing of a people's culture," while the second aspect is "the conscious elevation of the language of the

\footnotetext{
${ }^{19}$ Bhabha, 86.

${ }^{20}$ Bhabha, 89.

${ }^{21}$ Ngũgĩ wa Thiong'o, Decolonising the Mind: The Politics of Language in African Literature (London: Library of Congress Cataloging in Publication Data, 1986), 16.
}

colonizer."22 These two aspects are actually interrelated to each other, which means colonialism tries to degrade the colonized's own cultures (including their art and literature) and boost the colonizer's ideas imposed in the colonized's mind. Language is a concrete medium for colonialism to implement the decolonization of the mind. When the colonized people slowly leave their native language and start adopting and using the colonizer's language, it will affect their perception of their own identity, culture, and language.

Besides the theories explained previously, the analysis and statements written in this research were also supported by other articles and books. These secondary data give more elaborations about the issues of westernization and colonization of the mind raised in the short story.

\section{Results}

The "Dead Men's Path" was published in 1953 during the British colonialization in Nigeria. The main character of this story is a young headmaster named Michael Obi. $\mathrm{He}$ is promoted and assigned by the Mission authorities to handle Ndume Central School because he has great achievements concerning education as his expertise. Besides, the school has been unprogressive, so the Mission authorities choose a young man who is full of energy and innovations like him to be placed there. During the period when

${ }^{22}$ Thiong'o, 16. 
he rules this school, he tries his best to design the school as modern as possible. He decorates the school so that it looks better and develops a high standard of teaching for those who will teach in that school. Besides Obi himself, his wife is also excited when she hears the news telling that her husband is promoted. She dreams of a modern life, which comes true soon after her husband becomes the headmaster of Ndume Central School.

From the opening of this short story, the readers might assume that Michael Obi is a very kind headmaster who wants to improve that school's educational system. The readers might also think that Obi's plans have worked well. However, besides the improvement he contributes to the school, there is an issue that occurs in the process, and then it leads to other big issues that are burdensome enough for Michael Obi. Moreover, other things might seem trivial, but they are actually the results of British colonialism in Nigeria.

In the following sections, we will discuss three aspects depicted in this short story that are influenced by British colonialism. They are westernization, the contradiction between two ideas, and management of land.

\section{Westernization}

One of the prominent impacts from imperialism is the infusion of the colonizers' ideas, concepts, language, and even lifestyle in the colonized. It is important to take note that imperialism, which becomes the starting point of colonialism, is the practice, the theory, and the attitudes of a dominating metropolitan center ruling a distant territory. ${ }^{23}$ It means that, basically, imperialism itself already has several influences towards the colonized. Imperialism dominates the colonized with its practice and ideas which will be implemented by the help of colonialism. Most colonies authorize some aspects of everyday ruling to indigenous people, which diminishes the foreign sovereignty criterion to some degree. ${ }^{24}$

Moreover, colonialism, as the continuation of imperialism, is related to the migration of foreign people to a place or country. There, they alter the local political, social, economic, and cultural frameworks inherent in the country or countries and gradually replace them with western ideals. ${ }^{25}$ Colonialism transmits the colonizers' ideas that might be totally different from the colonized's indigenous values. It opens the door for westernization to infuse Western ideas and cultures through colonialism. As one country goes further by occupying another country through colonialism, westernization becomes something practical that happens between the colonizer and the colonized.

Besides, colonialism aims to make the colonized almost the same as the

\footnotetext{
23 Edward Said, Culture and Imperialism (New York: Vintage, 1994), 9.

${ }^{24}$ George Steinmetz, "The Sociology of Empires, Colonies, and Postcolonialism," Annual Review of Sociology 40, no. 1 (2014): 77-103, https://doi.org/10.1146/annurev-soc-071913043131.

25 Umaru Abubakar Bala, "Colonialism and the Development in Nigeria: Effects and Challenges," International Affairs and Global Strategy 70 (2019): 9-20.
} 
colonizers but not quite, which is in line with Bhabha's theory about mimicry. In his essay entitled Of Mimicry and Man, he explains how mimicry actually has double articulation. The first one is "a complex strategy of reform, regulation, and discipline," which aims to show the colonizers' power towards the colonized, while the second articulation deals with the threats to the "normalized knowledge and disciplinary powers." ${ }^{26}$ Interestingly, the concept of mimicry proposed by Bhabha and its impacts are also shown in this story even from the Nigerians themselves, particularly related to westernization in terms of modern Western lifestyle and perspective.

Furthermore, modern life is one of the characteristics that the colonizers usually bring to the colonized. In the story, Michael Obi is portrayed as a young man who is very open to - even he admires modern things and ideas, and his wife shares a similar perspective as well. It can be seen from the conversation between Obi and his wife. They discuss their dream of a modern life since Obi has been promoted by the Mission authorities due to his good level of education and strong intention to make the educational system better. However, the life that they are wishing is a modern one which is surely different from the Nigerian "lifestyle" they are living right now. It is stated clearly in the story by the author:

"We shall have such beautiful gardens, and everything will be just modern and delightful ..." In their two

${ }^{26}$ Bhabha, The Location of Culture, 86. years of married life, she had become completely infected by his passion for "modern methods" and his denigration of "these old and superannuated people in the teaching field who would be better employed as traders in the Onitsha market."

Both Obi and his wife want to show that modern life is much better than the other native Nigerians' lives. It shows that Michael Obi and his wife indirectly agree that the British colonizers and everything that defines them is way more excellent. They think that by adopting modern life as what the Westerners do, they will be seen as more superior than the Nigerians and considered on the same level as the Westerners, as cited in the following quotation:

"The wives of the other teachers would envy her position. She would set the fashion in everything ... Then, suddenly, it occurred to her that there might not be other wives. Wavering between hope and fear, she asked her husband, looking anxiously at him."28

However, the actual problem lies in the role of the institution towards their perspective. The ideas and even ideology from the colonizers can be spread through an institution, including the school where Obi obtains his degree. In this case, Western modernism is the concept that Obi absorbs from the institution and shares with his wife later. The knowledge he got from the institution does not bring his attention closer to the indigenous cultures that need to be preserved.

27 Chinua Achebe, "Dead Men's Path," in Girls at War and Other Stories (New York: Anchor Books, 1973).

${ }^{28}$ Achebe, "Dead Men's Path." 
Otherwise, his perspective is directed closer to Western ideas, making him fancy Western values that he sees as more "modern" than Nigerian cultures. This is one of the ways of how westernization works and comes into the natives. The impact is that Obi and his wife mimic Western lifestyles, which they consider more modern and comfortable and tend to leave the Nigerian identity they used to hold. It proves that mimicry can take several forms, such as imitating the colonizers' behavior, clothing, speech, and lifestyle. ${ }^{29}$

This situation also shows how influential the role of an educational institution is. It can be a medium to establish a new perspective that is inclined to Western ideas rather than introducing and keeping cultural values. His obedience and tendency towards Western values are the articulation of mimicry since the colonizers slowly reform the colonized's way of thinking, starting from the elites first, to visualize its power dominating the colonized. ${ }^{30}$ Duke II also states a similar argument, that colonialism has become the foundation of culture in modern Nigerian organizations. ${ }^{31}$ If Obi can be more critical of the Western ideas

${ }^{29}$ Sulistyaningsih Sulistyaningsih and Dina Merris Maya Sari, "The Ideological Reflection in F. Scott Fitzgerald's Novel, The Great Gatsby, (PostColonial Literature)," ATAVISME 21, no. 1 (2018): 121-32,

https://doi.org/10.24257/atavisme.v21i1.439.121132.

${ }^{30}$ Bhabha, The Location of Culture, 86.

31 Joe Duke II, "The Impact of Colonialism on the Development of Management in Nigeria," International Journal of Business and Management 5, no. 8 (2010): 65-75, https://doi.org/10.5539/ijbm.v5n8p65. he learns from the school, the second articulation of mimicry will work since he is able to see the things that are not suitable or even threatening for Nigerian cultures. Furthermore, the modern perspective that Obi holds influences most of his actions, which will be discussed in the second section about the contradiction between two ideas.

\section{Colonization of the Mind}

It is arguably true that in "Dead Men's Path," westernization changes the colonized's perspectives and identity. From the story, we can see that Western ideas, either directly or indirectly, influence some Nigerian elites, including Michael Obi. They start adopting new perspectives which are sometimes against their own cultures. As a result, what they are doing and thinking about is mostly based on Western ideas and thoughts.

When they meet people whose ideas are different from theirs, there is a collision between both points of view. The indigenous people strive to preserve the native cultures living for generations. At the same time, the colonizers and the colonized who have been westernized insist on eradicating the cultures which they consider as old and irrelevant compared to today's era where everything has been modern and more logical. This moment can be observed from Obi's experience in handling this contradiction.

It all begins when he notices that there is a path near his school which is often used by villagers. Even though the path is rarely used, this path is very important for the native people living near 
that area, as shown in the conversation between Obi and his colleague:

""It amazes me," said Obi to one of his teachers who had been three years in the school, "that you people allowed the villagers to make use of this footpath. It is simply incredible." $\mathrm{He}$ shook his head.

"The path," said the teacher apologetically, "appears to be very important to them. Although it is hardly used, it connects the village shrine with their place of burial."'32

Obi does not want the villagers' rituals and mobility to disturb the teaching and learning process, so he decides to close this path by planting heavy sticks and barbed wire. $\mathrm{He}$ is also afraid of ruining his reputation if the Government Education Officer comes to the school and finds that he cannot handle such a small problem. It shows that he does not care about the consequences of destroying culture as long as it can be profitable for him, as cited below:

"'What will the Government Education Officer think of this when he comes to inspect the school next week? The villagers might, for all I know, decide to use the schoolroom for a pagan ritual during the inspection."'”33

Because of his decision to close the path, a village priest of Ani comes to negotiate with Obi. He argues that the ancestral footpath is a part of their tradition that has to be preserved.

""Look here, my son," said the priest bringing down his walking stick, "this path was here before you were born

${ }^{32}$ Achebe, "Dead Men's Path."

${ }^{33}$ Achebe, "Dead Men's Path." and before your father was born. The whole life of this village depends on it. Our dead relatives depart by it, and our ancestors visit us by it. But most important, it is the path of children coming in to be born... "'34

However, Obi rejects such idea, initiating the point where Obi's modern perspective contradicts the priest's culture. After listening to the priest's argument, Michael Obi explains to the priest that what he and the villagers believe about the ancestral footpath does not make sense anymore. For Obi, the idea of sparing a footpath for ancestors is already outdated. This contradiction is one of the impacts of British colonialism in Nigeria. It can be observed from his statement:

"The whole purpose of our school," he said finally, "is to eradicate just such beliefs as that. Dead men do not require footpaths. The whole idea is just fantastic. Our duty is to teach your children to laugh at such ideas." ${ }^{\text {J5 }}$

In this case, we can observe the colonization of the colonized's mind as what Ngũgĩ wa Thiong'o has proposed. Besides occupying the land, the colonizers also need to control the colonized's mental in order to successfully implement their colonial pusposes. Moreover, colonization of mind actually involves two processes, namely; (1) The destruction or the deliberate undervaluing of a people's culture, and (2) The conscious elevation of the language of the colonizer. $^{36}$

\footnotetext{
${ }^{34}$ Achebe, "Dead Men's Path."

${ }^{35}$ Achebe, "Dead Men's Path."

${ }^{36}$ Thiong'o, Decolonising the Mind: The Politics of Language in African Literature, 16.
} 
From Obi's situation, it is clear that the first process of colonization of mind has occurred to him. His mental as a colonized has been infused by the colonizer's values through the institution where Obi obtained his degree. Later, this mental control continues to later generations through the same medium, which is school or institution. Based on the quotation above, Obi explains to the priest that the role of education in Nigeria is to "laugh at such ideas." That is to say, Obi and all of the teachers working in that school (which is, of course, influenced by the Western standard of education) are committed to teaching modern and Western values to the Nigerian students instead of their own cultures and nationality. We can see the concrete result of this first process in Obi himself. $\mathrm{He}$ consciously starts to undervalue the Nigerian culture and refuses to admit that he is still part of that culture.

While the first process of colonization of mind has done, the second process might need some time to be fully implemented. However, this short story has shown some signs of this second process. Again, it practically can be seen through education. For example, although it is not shown explicitly in the story, we can argue that Michael Obi must use English while talking to the Government Education Officer. It is possible for Obi to speak English fluently since he is one of the Nigerian elites who have privileges as a headmaster to deal with Western education in Nigeria. Later, as a headmaster who manages his school under the regulation given by the
Government Education Officer, it is likely for him to include English subjects into the curriculum as well. Once it is done, then colonization of mind is completely penetrated the colonized's life.

Furthermore, Michael Obi has already developed a perspective that is only based on logical things. It seems he has completely lost his understanding of honoring traditions. He refuses to respect his own culture because he thinks that several cultural values are not practical in the modern era in which he and the villagers live. Obi's argument proves the impact of which undermines the value of cultures and traditions which is according to Said, going native can only be the result of mutilation, which produces a diseased, ultimately unacceptable loss of identity. ${ }^{37}$ Michael Obi himself actually has already lost his identity as a Nigerian since he adopts Western values in almost every aspect of his life. It makes him unaware of some of his actions that can endanger the beliefs and cultures conserved by the villagers.

\section{Management of Land}

Even though the short story does not explicitly state the role of colonizers, it can still be observed from how British colonialism also impacts the management of land in Nigeria, especially the native's land. Colonialism develops to a notion of property and land in more formal theories of political philosophers, legal scholars, and political economists, which later aims

${ }^{37}$ Said, Culture and Imperialism, 178. 
to make the land become the colonizer's asset. $^{38}$

In "Dead Men's Path," imperialism accommodated in colonialism plays its role in managing the native people's land through Nigerian elites, including Michael Obi. It can be seen from the issue of ancestral path discussed earlier. The villagers believe that the path near Ndume Central School is very important for their ancestors and also for the children coming in to be born, but Obi thinks the opposite. He argues that the ancestral path should be closed so that the villagers will not use the area near Ndume Central School for their rituals.

However, the fact behind this problem is that the school is actually owned (or even managed) by the Government Education Officer whom Chinua Achebe describes as a white person. Moreover, Michael Obi is just a Nigerian elite who is chosen to be the headmaster, so Michael Obi always tries to fulfill his tasks in order to run the school well and satisfy the white Supervisor who will inspect the school, including preventing "obstacles" such as the ancestral path and a pagan ritual done by the villagers. It can be seen from how he explains to the priest that he has no choice either to defend the priest's request. Instead, he offers an alternative for the villagers to build another way for the ancestors, which actually does not really solve the problem:

38 David Ress, Deeds, Titles, and Changing Concepts of Land Rights: Colonial Innovations and Their Impact on Social Thought (London: Palgrave Macmillan, 2020), 3.
"I am sorry," said the young headmaster. "But the school compound cannot be a thoroughfare. It is against our regulations. I would suggest your constructing another path, skirting our premises. We can even get our boys to help in building it. I don't suppose the ancestors will find the little detour too burdensome."”39

From this situation, we can see how Western imperialism makes use of Nigerian elites to "clear the land" for them. They believe that it will be easier to change the indigenous people's mind through the elites who are similar to them in terms of nationality. It is in line with Spivak's explanation which is derived from Macaulay's statement about a plan to form a class of people who are native "in blood" but English "in taste and opinions." 40 Michael Obi is one of the people who is included in this class. Achebe describes him as the colonizers' right arm to carry on the plans that the colonizer has formed since he has already adopted Western ideas instead of his own Nigerian cultures. In this story, education is chosen by the author as a place where this situation can occur. Again, education as a part of the institution becomes a medium for imperialism to spread the colonizer's values and ideas.

However, the story ends with a surprising event. A young woman dies in a childbed, and the villagers believe that the reason is that the ancestral path has been closed, so they fight back against the rule

\footnotetext{
${ }^{39}$ Achebe, "Dead Men's Path."

${ }^{40}$ Gayatri Chakravorty Spivak, "Can the Subaltern Speak?," in Marxism and the Interpretation of Culture, ed. Cary Nelson and Lawrence Grossberg (Urbana: University of Illinois Press, 1988), 282.
} 
Obi has proposed in order to restore the peace in their village. This moment shows a turning point where the native people realize their own identity, trying to keep their cultures alive. Moreover, these people still have a strong sense of unity to fight for justice and their land rights. This unity then becomes their strength to deal with the impacts caused by Western imperialism in their area.

The findings of this research elaborated previously are important to readers who are interested in postcolonial literature and study. These findings can help readers track down the impacts of colonialism in the form of westernization and colonization of the mind as raised and discussed in "Dead Men's Path." The discussions about westernization and colonization of the mind depicted in "Dead Men's Path" can also open more opportunities for critics who want to study similar texts under the umbrella of postcolonial study.

In connection with previous studies, this research provides a more in-depth analysis of colonialism's impact, which is more focused on the issue of westernization and colonization of the mind as described in literary works. This study shows tangible evidence of the impact of westernization and colonization of the mind as depicted in the situation in "Dead Men's Path" involving Nigerian intellectuals and enriches the discussion of postcolonialism in Nigerian literature.

Studying postcolonial literature like "Dead Men's Path" can provide more insights into the impacts of colonialism depicted in literary works, especially in relation to the issues of westernization and colonization of the mind. These problems might have been deeply rooted not only within the colonized people living during colonial time but also futher generations in that particular country. In conclusion, Chinua Achebe's "Dead Men's Path" illustrates how westernization and colonization of the mind have changed the mindset of Nigerian intellectuals who belong to the colonized and affected their perceptions towards their own cultures, as happened to Michael Obi.

\section{Conclusion}

From the analysis of "Dead Men's Path" using postcolonial theories of mimicry and colonization of the mind proposed by Homi Bhabha and Ngũgĩ wa Thiong'o, it can be concluded that there are three issues raised by Chinua Achebe in relation to Western imperialism and colonialism in the colonized countries, especially Nigeria. The first issue is modernism in terms of the mimicry of lifestyle and culture perspective adopted by Michael Obi and his wife from the institution, particularly education. The second one is the contradiction between two ideas happening between Michael Obi, who rejects the culture of preserving ancestral path as a result of colonization of the mind by the modern Western ideas, and the villagers who still want to preserve the ancestral path in order to keep their culture alive for further generations. The last issue is related to the management of land that is held by the colonizers and is done through Nigerian elites as their right arms. These three issues prove that 
British imperialism and colonialism have great impacts on the colonized, and some of them can destroy the indigenous cultures that are rich and important for the sustainability of the native people's lives and society.

This study is still limited to the discussion of westernization and colonization of the mind seen from Nigerian intellectuals' perspectives. In contrast, more areas can still be studied, such as connecting westernization and colonization of the mind in the short story with feminist or environmental issues. Therefore, it is hoped that further researchers can review this short story and find gaps that can still be studied, especially related to the problem of westernization and colonization of the mind concerning other issues, such as the role of women during colonialism and exploitation of natural resources

\section{References}

Achebe, Chinua. "Dead Men's Path." In Girls at War and Other Stories. New York: Anchor Books, 1973.

Bala, Umaru Abubakar. "Colonialism and the Development in Nigeria: Effects and Challenges." International Affairs and Global Strategy 70 (2019): 9-20.

Bhabha, Homi K. The Location of Culture. London: Routledge, 1994.

Casimir, Komenan. "Promotion of Igbo Culture in Chinua Achebe's Girls at War and Other Stories." Global Journal of Arts, Humanities and Social Sciences 6, no. 9 (2018): 2641.

Duke II, Joe. "The Impact of Colonialism on the Development of Management in Nigeria." International Journal of
Business and Management 5, no. 8 (2010): $65-75$. https://doi.org/10.5539/ijbm.v5n8p65.

Garuba, Harry. "Chinua Achebe and the Struggle for Discursive Authority in the Postcolonial World." PMLA 129, no. 2 (2014): 246-48. https://www.jstor.org/stable/2476945 3.

Nensilianti, Sy. Fatma Al-Khiyyed, and Hasvivi Tri Anjarsari Fahrir. "Colonial Racial Ethnocentrism Towards Indigenous People in a Short Story Collection 'Semua Untuk Hindia' by Iksaka Banu (A Postcolonial Study)." OKARA: Jurnal Bahasa dan Sastra 15, no. 1 (2021): 1-21.

https://doi.org/10.19105/ojbs.v15i1.3 982.

Nwinya, Stephen Chijioke. "The Conflate of Modernization and Westernization and Africa's Quest for Authentic Civilization and Development." IOSR Journal of Humanities and Social Science 24, no. 10 (2019): 59-65.

Ocheni, Stephen, and Basil C. Nwankwo. "Analysis of Colonialism and Its Impact in Africa." Cross-Cultural Communication 8, no. 3 (2012): 4654.

https://doi.org/10.3968/j.ccc.192367 0020120803.1189.

Overbey, Karen Eileen. "Postcolonial." Studies in Iconography 33 (2012): 145-56. https://www.jstor.org/stable/2392427 9.

Prianti, Desi Dwi. "Towards the Westernized Body: A Popular Narrative Reinforced by Men's Lifestyle Magazines in Indonesia." Inter-Asia Cultural Studies 19, no. 1 (2018):

103-16. https://doi.org/10.1080/14649373.20 18.1422351 .

Putri, Liza, and Katherine Clayton. "The Identity Issue of the Colonized and the Colonizer in Cloud Nine by Caryl Churchill." International Journal of 
Cultural and Art Studies 4, no. 1 (2020): $1-8$. https://doi.org/10.32734/ijcas.v4i1.3 620.

Ress, David. Deeds, Titles, and Changing Concepts of Land Rights: Colonial Innovations and Their Impact on Social Thought. London: Palgrave Macmillan, 2020.

Said, Edward. Culture and Imperialism. New York: Vintage, 1994.

Sairin, Sjafri. "Modernization and Westernization: A Never-Ending Discourse in Indonesia." Journal of Governance and Development 7 (2011): 1-7.

Seth, Sanjay. "Postcolonial Theory and the Critique of International Relations." Millennium 40, no. 1 (2011): 167-83. https://doi.org/10.1177/0305829811 412325 .

Sibani, Clifford Meesua. "Impact of Western Culture on Traditional African Society: Problems and Prospects." International Journal of Religion and Human Relations 10, no. 1 (2018): 56-72.

Souad, Merah, and Tahraoui Ramdane. "Learning English in the 21st Century: For Globalization or Westernization?" International Journal of Humanities and Social Science 9, no. 6 (2019): 165-72. https://doi.org/10.30845/ijhss.v9n6p 20.

Spivak, Gayatri Chakravorty. "Can the Subaltern Speak?" In Marxism and the Interpretation of Culture, edited by Cary Nelson and Lawrence Grossberg. Urbana: University of Illinois Press, 1988.

Steinmetz, George. "The Sociology of Empires, Colonies, and Postcolonialism." Annual Review of Sociology 40, no. 1 (2014): 77-103. https://doi.org/10.1146/annurev-soc071913-043131.
Sulistyaningsih, Sulistyaningsih, and Dina Merris Maya Sari. "The Ideological Reflection in F. Scott Fitzgerald's Novel, The Great Gatsby, (PostColonial Literature)." ATAVISME 21, no. 1 (2018): 121-32. https://doi.org/10.24257/atavisme.v2 1i1.439.121-132.

The Editors of Encyclopaedia Brittanica. "Chinua Achebe: Nigerian Author." In Encyclopedia Britannica. Accessed October 25, 2021. https://www.britannica.com/biograph y/Chinua-Achebe.

Thiong'o, Ngũgĩ wa. Decolonising the Mind: The Politics of Language in African Literature. London: Library of Congress Cataloging in Publication Data, 1986.

Uysal, Nuriye Degirmenci. "Teaching English to Very Young Learners." Procedia - Social and Behavioral Sciences 197, no. 2 (2015): 19-22. https://doi.org/10.1016/j.sbspro.201 5.07.042.

Young, Robert JC. "Postcolonial Remains." New Literary History 43, no. 1 (2012): 19-42. https://doi.org/10.1353/nlh.2012.0009. 